Volume 1

\title{
Lookin Beyond the Charitable Trust Debate to Amend, Enforce, or Terminate Conservation Easements
}

Erin M. Clifft

Texas A\&M University School of Law

Follow this and additional works at: https://scholarship.law.tamu.edu/journal-of-property-law

Part of the Law Commons

\section{Recommended Citation}

Erin M. Clifft, Lookin Beyond the Charitable Trust Debate to Amend, Enforce, or Terminate Conservation Easements, 1 Tex. A\&M J. Real Prop. L. 197 (2013).

Available at: https://doi.org/10.37419/JPL.V1.I2.3

This Student Article is brought to you for free and open access by Texas A\&M Law Scholarship. It has been accepted for inclusion in Texas A\&M Journal of Property Law by an authorized editor of Texas A\&M Law Scholarship. For more information, please contact aretteen@law.tamu.edu. 


\title{
LOOKING BEYOND THE CHARITABLE TRUST DEBATE TO AMEND, ENFORCE, OR TERMINATE CONSERVATION EASEMENTS
}

\author{
By Erin M. Clifft $\dagger$
}

I. Introduction.................................... 197

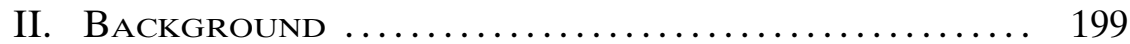

A. Uniform Conservation Easement Act ("UCEA") .... 199

B. Internal Revenue Code and Regulations........... 200

III. The Debate Over the Charitable Trust

Doctrine .................................. 201

A. Charitable Trust Doctrine and Cy Pres Proceedings. 201

B. Reasons for Treating Conservation Easements as Charitable Trusts.......................... 202

C. Reasons Against Treating Conservation Easements as Charitable Trusts............................ 205

IV. States' Solutions ............................. 207

A. Comprehensive Amendment and Termination Restrictions............................... 209

1. Massachusetts.......................... 209

2. Montana ............................... 209

3. Nebraska ............................... 209

4. Maine................................ 210

B. Standing of States' Attorneys General ............ 212

V. Adaptive Land Management Concerns and

AnAlysis ......................................... 214

VI. Conclusion ...................................... 217

\section{INTRODUCTION}

As of year-end 2010, state and local land trusts have protected almost nine million acres of land in the United States under conservation easements. ${ }^{1}$ Conservation easements are negative "servitude[s] created for conservation or preservation purposes." 2 As a tool for private parties to conserve land, a conservation easement is a less-than fee, non-possessory property interest, usually held by a qualified land

$\dagger$ Author Bio: J.D. Candidate, Texas A\&M University School of Law, Spring 2014; B.B.A., Middle Tennessee State University, 2005; Notes \& Comments Editor, Texas A\&M Journal of Real Property Law, 2013-2014.

1. Katie Chang, 2010 National Land Trust Alliance Census Report, Land Trust Alliance, 5 (Rob Aldrich \& Christina Soto eds., 2011), http://www.landtrustalliance.org/land-trusts/land-trust-census/2010-final-report; Jessica E. Jay, When Perpetual is Not Forever: The Challenge of Changing Conditions, Amendment, and Termination of Perpetual Conservation Easements, 36 Harv. Envtl. L. Rev. 1, 2 (2012).

2. Restatement (Third) of Prop.: Servitudes $§ 1.6(1) \&$ cmt. a (2000). DOI: https://doi.org/10.37419/JPL.V1.I2.3 
trust or government entity, which "imposes permanent restrictions on the use of land through negative limitations or affirmative obligations." 3

Most states have enacted conservation easement enabling laws based on the Uniform Conservation Easement Act ("UCEA"), which was adopted in 1981 by the National Conference of Commissioners on Uniform State Laws ("National Conference") and amended in 2007. ${ }^{4}$ The National Conference designed the UCEA to "overcome the common law's aversion to a negative easement held in gross." ${ }^{5}$ The common law allowed the creation of negative easements for only four purposes: light, air, support of buildings, and artificial streams-none of the listed purposes supported the protection of open space or natural resources. ${ }^{6}$ Although a conservation easement is an agreement between private parties about what is permissible on the burdened land, traditional property rules govern the modification and termination of conservation easements. ${ }^{7}$

There is no uniform way, currently, to handle amendments and terminations of perpetual conservation easements. ${ }^{8}$ Should real property law, charitable trust doctrine, or state legislatures supply the answers? This Comment begins by briefly describing the background law and principles relating to conservation easements. Then, this Comment will discuss the debate over whether charitable trust doctrine should apply when enforcing, modifying, or terminating perpetual conservation easements. Additionally, this Comment will highlight some of the different state approaches to this relatively new problem. Most states that have adopted the UCEA are silent regarding how charitable trust law relates to conservation easement enforcement, but a few have potentially comprehensive solutions. ${ }^{9}$

This Comment will recommend a uniform solution. Conservation easements are a hybrid-law creation, and the solution to modifying and terminating perpetual easements should be a hybrid one as well. The hybrid solution must address, in a holistic manner, the other diffi-

3. Jay, supra note 1 , at 3 .

4. Jeff Pidot, Conservation Easement Reform: As Maine Goes Should the Nation Follow?, 74 Law \& Comtemp. Probs., Issue 4 Fall 2011, at 1, 3; Robert H. Levin, A Guided Tour of the Conservation Easement Enabling Statutes, LAND Trust AlliANCE 7 (Sept. 14, 2013, 3:09 PM), http://www.landtrustalliance.org/policy/emergingissues/cestatutesreportnoappendices.pdf.

5. Matthew J. Richardson, Conservation Easements as Charitable Trusts in Kansas: Striking the Appropriate Balance Among the Grantor's Intent, the Public's Interest, and the Need for Flexibility, 49 WAshBurN L.J. 175, 179 (2009).

6. C. Timothy Lindstrom, Hicks v. Dowd: The End of Perpetuity?, 8 Wyo. L. REv. 25, 37 (2008); see also id. at n.62.

7. Jessica Owley, Changing Property in a Changing World: A Call for the End of Perpetual Conservation Easements, 30 Stan. EnvTL. L.J. 121, 137 (2011).

8. Jay, supra note 1 , at 3.

9. A complete look at all fifty states' statutes and common law relating to easement modification and termination is beyond the scope of this Comment. 
culties surrounding conservation easements, like adaptive land management and enforcement. This Comment will not delve too deeply into the issues surrounding conservation easements and adaptive land management, but will touch on some concerns that might affect the debate over the charitable trust doctrine in the future.

\section{BACKGROUND}

\section{A. Uniform Conservation Easement Act ("UCEA")}

The National Conference creates uniform acts that state legislatures may or may not adopt as law. ${ }^{10}$ The basic goal of the UCEA is to "remove outmoded common law defenses that could impede the use of easements for conservation or preservation ends." 11 The UCEA defines conservation easement as a:

$[\mathrm{N}]$ onpossessory interest of a holder in real property imposing limitations or affirmative obligations the purposes of which include retaining or protecting natural, scenic, or open-space or real property, assuring its availability for agricultural, forest, recreational, or openspace use, protecting natural resources, maintaining or enhancing air or water quality, or preserving the historical, architectural, archaeological, or cultural aspects of real property. ${ }^{12}$

Conservation easements are a separate interest from the common law real covenants, equitable servitudes, and easements, but they are a combination of those common law interests to further conservation purposes. ${ }^{13}$ The term "easement" was chosen, among other reasons, because the act is intended to be placed in the real property law of adopting states. ${ }^{14}$ Under the UCEA, "a conservation easement may be created, conveyed, recorded, assigned, released, modified, terminated, or otherwise altered or affected in the same manner as other easements." 15 The UCEA leaves intact a court's ability to "modify or terminate a conservation easement in accordance with principles of law or equity," which might include real property law and charitable trust doctrine. ${ }^{16}$ The drafters point out that, although the real property changed-conditions doctrine is applied in all states, its application to conservation easements is "problematic" in many states. ${ }^{17}$ However, "the drafters do not explain why the changed-conditions doctrine is problematic." 18

10. Jay, supra note 1 , at 26.

11. Uniform Conservation Easement Act $\S 4$, cmt. (2007).

12. § 1(1).

13. Uniform Conservation Easement Act, Prefatory Note at 1-2.

14. $\S 3, \mathrm{cmt}$.

15. $\S 2(\mathrm{a})$.

16. § 3(b).

17. $\S 3, \mathrm{cmt}$.

18. Jay, supra note 1 , at 29. 
The Act does not directly apply charitable trust principles to conservation easements to avoid conflicting with the laws of adopting states. ${ }^{19}$ Nevertheless, because conservation easements are conveyed to charitable organizations and government entities for a specific public or charitable purpose, the comment to section 3 of the Act suggests the law of adopting states as it relates to the enforcement of charitable trusts should apply to conservation easements. ${ }^{20}$ The Act does suggest that a state's attorney general would have standing to bring an action to enforce a conservation easement as a charitable trust. ${ }^{21}$ The Act only allows this third-party enforcement right in governmental or qualified charitable organizations. ${ }^{22}$

\section{B. Internal Revenue Code and Regulations}

In addition to promoting environmental conservation or historical preservation, a large motivating factor in a landowner's decision to convey a conservation easement is gaining a favorable tax deduction. ${ }^{23}$ The Department of Treasury regulations ("Regulations") that flow from the Internal Revenue Code section 170(h) require that the "qualified property interest" is "guaranteed in perpetuity" and given to a "qualified organization exclusively for conservation purposes" to receive a deduction for a conservation easement. ${ }^{24}$ Section $170(\mathrm{~h})$ of the Code provides donors an income-tax deduction for conservation easements with conservation purposes. ${ }^{25}$ Congress intended to provide federal tax subsidies for conservation easement donations only if they "would permanently protect the conservation or historic values of unique" properties to curtail abuse of the subsidy. ${ }^{26}$ The conservation easement as a "qualified property interest" is given in perpetuity, and the "conservation purpose" must be protected in perpetuity. ${ }^{27}$ So far, Congress has not considered the modification of perpetual conservation easements. ${ }^{28}$

The only way a perpetual conservation easement may be transferred from one qualifying organization to another is if the receiving qualifying organization agrees to follow the perpetual conservation purposes. ${ }^{29}$ The Regulations and the Code allow for conservation

19. Uniform Conservation Easement Act, Prefatory Note at 3 (amended 2007).

20. $\S 3$, cmt.

21. Id.; Richardson, supra note 5, at 183.

22. Richardson, supra note 5, at 183.

23. Id.

24. Treas. Reg. § 1.170A-14; Pidot, supra note 4, at 3.

25. Jay, supra note 1 , at 6 .

26. Nancy A. McLaughlin, Internal Revenue Code Section 170(h): National Perpetuity Standards for Federally Subsidized Conservation Easements, Part 1: The Standards, 45 Real Prop. TR. \& Est. L.J. 473, 475 (2010).

27. Jay, supra note 1 , at $6-8 ; 26$ U.S.C. $\$ \S 170(\mathrm{~h})(1),(\mathrm{h})(2)(\mathrm{C}),(\mathrm{h})(5)(\mathrm{A})(2006)$.

28. $I d$.

29. Id. 
easement termination in certain instances. ${ }^{30}$ One instance in which a conservation easement may be terminated is when changes to the property occur that were unexpected at the time of the conservation easement donation that makes "it impossible or impractical to achieve the easement's conservation purposes." 31 The Regulations do not expressly provide for amendment between changes to the property and termination. ${ }^{32}$ This mirrors the original application of the changedconditions doctrine, which has since allowed for an easement's modification prior to termination..$^{33}$

Some have interpreted the Regulations to allow for amendment if changed conditions make impossible or impractical the "continued use of the property for conservation purposes, the conservation purpose can nonetheless be treated as protected in perpetuity." ${ }^{4}$ One could interpret this as any conservation purpose will do, and when no conservation purpose is possible, then the easement may be terminated. ${ }^{35}$ But it is unclear whether the IRS would follow this interpretation because of the lack of language describing an intermediate step, and the Regulation's drafters did not consider amendment at the time. ${ }^{36}$

\section{The Debate Over the Charitable Trust Doctrine}

Conservation easements may be subject to both trust and real property law simultaneously. ${ }^{37}$ Trust law is usually set apart for charitable trusts, and real property law is usually set apart for real property servitudes. ${ }^{38}$ This "dual reliance on trust and real property law places decision-makers in the difficult position of determining when and how to apply" the respective laws. ${ }^{39}$

\section{A. Charitable Trust Doctrine and Cy Pres Proceedings}

At common law, a charitable trust is created when a donor makes a charitable contribution subject to restrictions on its use like a cash contribution given to spend as the charity sees fit or when a trust lim-

30. Id. at 6-7.

31. Id. at 9 .

32. Id.

33. Id. at 10.

34. Id.; Treas. Reg. $§ 1.170 \mathrm{~A}-14(\mathrm{~g})(6)(\mathrm{i})$ ("Impractical" as used in the Regulations is a notable step down from the Restatement's higher standard of "impracticable."). See Restatement (Third) of Prop.: Servitudes $\$ 7.11$ (2000).

35. Jay, supra note 1 , at 10-11.

36. Id.

37. Id. at 22 .

38. Id.

39. Id. 
its property to some public use. ${ }^{40}$ While traditional trusts are subject to durational restrictions, charitable trusts may be perpetual because they benefit the public and overcome dead-hand control concerns. ${ }^{41}$ Another way charitable trusts differ from traditional trusts is that no classic trust language is required - the only requirement is the donor's charitable intent. ${ }^{42}$ Charitable trusts create fiduciary duties in the trustee. ${ }^{43}$ Members of the public generally do not have standing to enforce charitable trusts, but a state's attorney general may have express or implied powers to enforce. ${ }^{44}$

The doctrine of cy pres allows courts to modify charitable trusts when they become impracticable while accounting for the public's interest. ${ }^{45}$ The term comes from the French "cy pres comme possible" meaning "as near as possible" or "as near as may be." 46 The doctrine of cy pres has the following three elements: (1) the donor created or intended to create a trust for charitable purposes; (2) the specific purpose of the trust is impossible or impracticable to carry out; and (3) the donor manifested a general charitable intention. ${ }^{47} \mathrm{~A}$ court will apply this doctrine to carry out a donor's general charitable intent, rather than allow the trust to fail. ${ }^{48}$

\section{B. Reasons for Treating Conservation Easements as Charitable Trusts}

A conservation easement may be a restricted charitable gift, and therefore a charitable trust making the recipient subject to certain fiduciary duties to administer that trust. ${ }^{49}$ A restricted charitable gift "is a contribution of money or property that the donor makes to a government entity or charitable organization to be used for a specific charitable purpose."50 Conservation easements donated to government entities and land trusts, usually in perpetuity, have the specific charitable purpose of protecting the encumbered land according to the conservation purposes listed in the deed of conveyance. ${ }^{51}$

40. David J. Dietrich \& Christian Dietrich, Conservation Easements: Tax and Real Estate Planning for Landowners and Advisors 165 (ABA Publishing eds., 2011).

41. Richardson, supra note 5 , at $185-86$.

42. Id.

43. Id. at $186-87$.

44. Id.

45. Id. at $185-86$.

46. Id. at 188; 88 Aм. Jur. 3d Proof of Facts $\S 469$ (2006).

47. Richardson, supra note 5, at 187.

48. Id. at 188 .

49. Nancy McLaughlin \& W. William Weeks, In Defense of Conservation Easements: A Response to The End of Perpetuity, 9 Wyo. L. Rev. 1, 3 (2009).

50. Id. at 2-3.

51. Id. at 5 . 
The Uniform Trust Code ("UTC") provides that a trust is created only if "[t]he settlor indicates an intention to create the trust." 52 To indicate intention to create a trust, the settlor needs to intend to create a fiduciary relationship so that "one person holds a property interest subject to an equitable obligation to keep or use it for the benefit of another." 53 The settlor does not have to use the word "trust" or "trustee" to create a charitable trust. ${ }^{54}$ Arguably, a conservation easement has all of these elements to make it a charitable trust: donation of property to governmental or charitable organization to be used for the specific purpose of protecting the encumbered land for conservation purposes specified in the deed of conveyance in perpetuity. ${ }^{55}$

Also, the Restatement (Third) of Property permits applying cy pres doctrine to modify conservation easements. ${ }^{56}$ Conservation easement donors realize they are gaining sizable federal and possibly state income tax deductions for making the charitable gifts intended to benefit the public. ${ }^{57}$ The 2007 amendments to the UCEA advocate, but do not require, the application of the charitable trust doctrine to conservation easement modification and termination. ${ }^{58}$ Besides leaving the state law of adopting states intact regarding "modification and termination of easements and the enforcement of charitable trusts," the Act states that separate from the Act "the Attorney General could have standing [to enforce a conservation easement] in his capacity as supervisor of charitable trusts . . .".59

However, charitable trust law is not precluded from governing conservation easements simply because property law already does. ${ }^{60}$ In fact, both property and charitable trust law govern gifts of fee title to land given to government entities or charitable organizations, such as parks, libraries, and hospitals. ${ }^{61}$ Professor McLaughlin explains that:

[A]lthough state real property law may provide that a conservation easement can be modified or terminated by agreement of the holder of the easement and the owner of the encumbered land ..., the holder of a perpetual conservation easement, in its capacity as trustee, may not agree to modify or terminate the easement in contravention of its stated purpose without first obtaining court approval in a cy pres proceeding. ${ }^{62}$

52. $I d$. at 20 .

53. Id. at $20-21$.

54. Id. at 22 (quoting Restatement (Second) of Trusts $\S 351 \mathrm{cmt}$. b).

55. Id. at 23-24.

56. Restatement (Third) of Prop.: Servitudes $§ 7.11$ (2000).

57. McLaughlin \& Weeks, supra note 49, at 24. 2007).

58. Uniform Conservation Easement Act, Prefatory Note at 1 (amended

59. § $3, \mathrm{cmt}$.

60. McLaughlin \& Weeks, supra note 49, at 30.

61. Id.

62. Nancy A. McLaughlin, Conservation Easements: Perpetuity and Beyond, 34 ECOLOGY L.Q. 673, 683 (2007). 
The Land Trust Alliance ("LTA") has published two articles that describe that the charitable trust doctrine is an applicable constraint on conservation easement amendments. ${ }^{63}$ The Regulations have also contemplated the application of charitable trust principles to tax-deductible conservation easements since $1986 .{ }^{64}$

Charitable trust principles neither require judicial approval of every amendment in a cy pres proceeding, nor preclude typical or reasonable amendments. ${ }^{65}$ The powers of the charitable trustee that apply to the modification and termination of conservation easements are: express, implied, exercisable pursuant to the doctrine of administrative deviation, and exercisable pursuant to cy pres. ${ }^{66}$ Express powers are discretionary and are enumerated in the terms of the trust or statute. ${ }^{67}$ Courts do not interfere with express powers unless there is clear abuse of the trustee's discretion. ${ }^{68}$ Therefore, conservation easements with clear provisions for amendments in the deed give the easement holder express power to agree with current and subsequent landowners to amend the conservation easement. ${ }^{69}$

Charitable trustees also have "implied powers" to do what is "necessary or appropriate" to carry out the purposes of the trust, and even absent express amendment provisions, the conservation easement holder may have implied power to agree to amendments that will further the purpose of the easement if not inconsistent with the terms. ${ }^{70}$ Unlike express powers, courts disfavor finding implied powers that are not expressly granted in the instrument. ${ }^{71}$

To the extent changed circumstances necessitate amendments to a conservation easement that exceed the holder's express or implied powers, the holder can seek judicial approval of such amendments pursuant to the doctrine of administrative deviation or the doctrine of $c y$ pres, as the case may be. These doctrines are distinct. The doctrine of administrative deviation applies to the modification of an administrative term (but not the purpose) of a trust, and is sometimes described as permitting a court to modify the means by which the purpose is to be accomplished. The doctrine of cy pres, on the other hand, applies to the modification of the charitable purpose of a trust. ${ }^{72}$

The doctrines of administrative deviation and cy pres are distinct: administrative deviation allows a court to modify the way the charita-

63. McLaughlin \& Weeks, supra note 49 , at 40-41.

64. Id. at 36 .

65. Id. at 41.

66. Id. at 42 .

67. Id.

68. $I d$.

69. $I d$. at 43 .

70. Id. at $47-48$.

71. Id. at 48 .

72. Id. at 49 . 
ble purpose is carried out and cy pres allows the court to modify the actual charitable purpose. ${ }^{73}$

Usually, only the state attorney general has standing to enforce a charitable trust or a restricted charitable gift. ${ }^{74}$ Others with standing to sue for enforcement of a conservation easement may include a cofiduciary, the donor, and sometimes a party with a "special interest" separate from the public. ${ }^{75}$ One reason for the state attorney general to have standing is that the attorney general protects people of the state and conservation easements benefit the public, so an extension of that protection is as supervisor and enforcer of conservation easements. $^{76}$

\section{Reasons Against Treating Conservation Easements as Charitable Trusts}

The UCEA allows for the modification or termination of conservation easements in the same manner as other easements. ${ }^{77}$ At common law, the parties to an easement have the right to "release" the easement back to the owner of the servient parcel. ${ }^{78}$ Another way to terminate an easement under common law is cessation of purpose, in which an easement is terminated when the purpose can no longer be carried out. ${ }^{79}$ Traditionally, only the easement holder had standing to enforce the easement. ${ }^{80}$

However, the doctrine of cy pres applies to the law governing charitable trusts, which makes the doctrine part of the law of trusts, and property law governs conservation easements. ${ }^{81}$ It is up to the landowner and the prospective easement holder to negotiate the terms of most conservation easements. ${ }^{82}$ If conservation easements are charitable trusts, then only the court can modify a conservation easement's purpose, which would represent a significant change from current land trust practice. ${ }^{83}$ The LTA itself is neutral concerning the debate over the charitable-trust doctrine. ${ }^{84}$

The biggest question is one of intent. The Uniform Trust Code ("UTC") provides that "a trust is created only if the settlor indicates an intention to create a trust." ${ }^{\circ 5}$ In addition, the law permits inferring

73. Id.

74. Id. at 62 .

75. $I d$. at 68 .

76. Id. at 63 .

77. Id. at 33 .

78. Lindstrom, supra note 6, at 44.

79. $I d$.

80. Id. at 63 .

81. Id. at 59 .

82. Id. at 61 .

83. Id. at 63 .

84. C. Timothy Lindstrom, Conservation Easements, Common Sense and the Charitable Trust Doctrine, 9 Wyo. L. REv. 397, 400 (2009).

85. Id. at 402. 
intent to create a trust, but the "inference is not to come easily ... and ... clear, explicit, definite, unequivocal, and unambiguous language or conduct establishing the intent to create a trust is required . . ." 86 Usually, conservation easements do not state that the rights to enforce the restrictions on the use of lands that comprise the easement are conveyed in trust. ${ }^{87}$ One argument is while it is correct that conservation easements are granted to governmental agencies and pubic charities and that such grants include specific purposes, whether they should create a charitable trust is open for debate and should not be inferred lightly. ${ }^{88}$ Unlike other gifts, conservation easements are splitinterest gifts in which the donor retains rights to use the land that is the subject of the gift. ${ }^{89}$ This distinction "complicates the inference of an intention to create a trust, even though such an inference may be appropriate to other types of gifts." 90

Applying cy pres to conservation easements may have four main consequences. ${ }^{91}$ First, authority would transfer to the courts to modify or terminate conservation easements. ${ }^{92}$ Second, it may increase the number of persons with standing to participate or bring a cy pres proceeding. ${ }^{93}$ Third, it may restrict the justifications for easement modification or termination and "preclude[d] most of the easement amendments that are typical today." 94 Finally, more court proceedings will increase the time and costs for easement termination and modification. ${ }^{95}$

Conservation easement donors may understand that they must give up the unilateral right to modify a conservation easement in return for qualifying for a tax deduction. ${ }^{96}$ But under $c y$ pres, landowners may not understand that they do not have the power to agree with land trusts to reasonable easement modifications apart from a judicial proceeding. ${ }^{97}$ Because parties with standing may argue for, as well as against, termination or modification under cy pres, what prevents a development-minded attorney general from filing suit seeking to apply cy pres to terminate an easement in favor of a developer seeking to develop the land covered by the conservation easement to boost the local tax revenue ${ }^{98}$ This possibility could undermine the purpose of the conservation easement and open up a cost-benefit analysis by

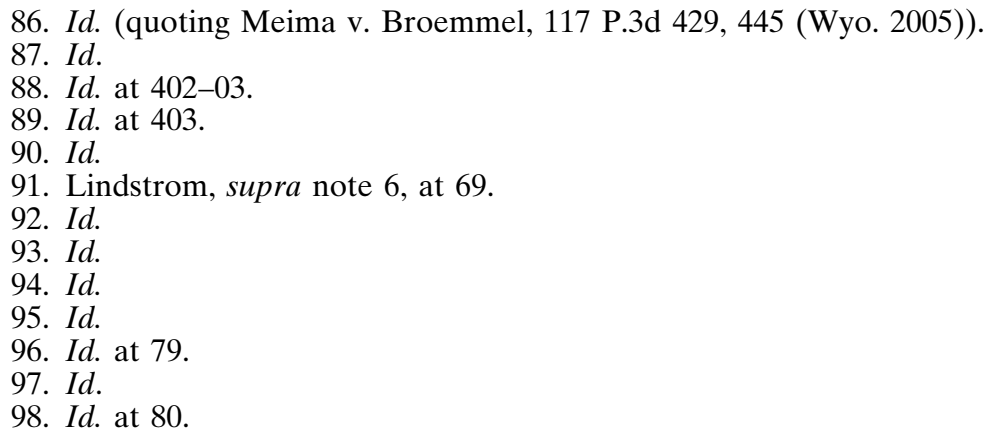


the courts balancing the value of an easement versus the value of new development." "The doctrine of cy pres was developed and refined over the centuries to carefully balance respect for donor intent with society's interest in ensuring that assets perpetually devoted to charitable purposes continue to provide an appropriate level of benefit to the public." "[I] t can be seen that conservation easements have not been made subject to the charitable trust doctrine, notwithstanding arguments that the doctrine should apply."

\section{States' Solutions}

The main issues found across state enabling statutes deal with amendment, termination, and standing to enforce conservation easements. ${ }^{102}$ Most states and the UCEA are silent on these issues, which creates ambiguity about how state laws on real property and charitable trusts apply. ${ }^{103}$ Most state enabling statutes were adopted before conservation easements became common, which explains the recent amendment activity. ${ }^{104}$ All states, except North Dakota, have enacted some conservation easement enabling legislation, twenty-seven states and the District of Columbia based their enabling statutes on the UCEA. ${ }^{105}$ In North Dakota, only the federal government may hold perpetual conservation easements; otherwise, they are limited to ninety-nine years or less. ${ }^{106}$

The LTA requires its member land trusts to adopt their standards and practices to renew membership and maintain national accreditation. ${ }^{107}$ At least one state, New Hampshire, has adopted the LTA Amendment Principles, which provide helpful guidelines for holders considering requests for conservation easement amendment or termination. ${ }^{108}$ To meet the LTA's Amendment Principles, a conservation easement should meet all of the following:

1. Clearly serve the public interest and be consistent with the land trust's mission.

2. Comply with all applicable federal, state, and local laws.

3. Not jeopardize the land trust's tax-exempt status or status as a charitable organization under federal or state law.

4. Not result in private inurement or confer impermissible private benefit.

99. Id.

100. McLaughlin \& Weeks, supra note 49, at n.330.

101. Lindstrom, supra note 84, at 405-06.

102. Levin, supra note 4, at 2.

103. Id.

104. Id. at 4.

105. Id. at 7 .

106. Id.

107. Jay, supra note 1 , at 31 .

108. Id. at 33. 
5. Be consistent with the conservation purpose(s) and intent of the easement.

6. Be consistent with the documented intent of the donor, grantor and any direct funding source.

7. Have a net beneficial or neutral effect on the relevant conservation values protected by the easement. ${ }^{109}$

In most states, conservation easements are created like any other real property transaction, as open or private as the parties' desire, except that conservation easements must be recorded. ${ }^{110}$ But in five states-Massachusetts, Montana, Nebraska, Oregon, and Virginiasome combination of public comment and approval process is required for the creation of a conservation easement. ${ }^{111}$

Oregon requires notice and a public hearing before any governmental entity can acquire a conservation easement, and Montana requires an advisory review of every easement to promote consistency with local planning agendas. ${ }^{112}$ Virginia's statute requires that conservation easements conform to local comprehensive plans at the time of conveyance to be valid, and some land trusts include letters from local planning officials in the easement. ${ }^{113}$

Massachusetts's easement approval process is very rigorous and has been in place since 1969. The Massachusetts Executive Office of Energy and Environmental Affairs ("EOEEA") must approve municipal and county-held conservation easements; and land trust-owned conservation easements must be approved by local governmental authorities and the EOEEA. ${ }^{114}$ The approving entities determine if the easement is in the public interest and consider conservation programs, land use, and development plans. ${ }^{115}$

Like Massachusetts, Nebraska requires municipal or county approval of all easements, except that state-held easements require planning commission review, but not approval. ${ }^{116}$ Connecticut, the District of Columbia, and Georgia coordinate their land use permit process with conservation easements. ${ }^{117}$

109. Id.; Land Trust Alliance, Amending Conservation Easements: Evolving Practices and Legal Principles, 17 (Aug. 2007), http://www.google.com/url?sa=t\&rct=j\&q= $\&$ esrc $=$ s \& frm $=1 \&$ source $=$ web $\& \mathrm{~cd}=3 \& \mathrm{cad}=\mathrm{rja} \& \mathrm{ved}=0 \mathrm{CD} 0 \mathrm{QFj} \mathrm{AC} \& \mathrm{url}=\mathrm{http} \% 3 \mathrm{~A} \%$ 2F\%2Fresources.cclt.org \%2Findex.php \%2Fstewardship \%3Fdownload\%3D37\%3A amending-conservation-easements-evolving-practices-and-legal-principles\&ei=V2Eh UoH3E6e9sQTwuYHADg\&usg=AFQjCNGnI4FM5gyswCWfH5FOFflVOQQp0g\& sig2=WeqR-QTVWJStVnh1vjNbQw\&bvm=bvBV.51495398,d.b2I.

110. Levin, supra note 4, at 10-11.

111. Id.

112. Id. at 12 .

113. Id.

114. $I d$.

115. Id.

116. Id. at 13 .

117. Id. 


\section{A. Comprehensive Amendment and Termination Restrictions}

Thirteen of fifty states provide some procedural and substantive restrictions on easement amendment and termination, and only four states have comprehensive amendment and termination restrictions: Maine, Massachusetts, Montana, and Nebraska. ${ }^{118}$ Some experts believe that the charitable trust doctrine provides clarity and no adjustments to enabling acts are necessary, and others believe that state laws are unclear and need adjustments to fit the specific needs of conservation easements. ${ }^{119}$

\section{Massachusetts}

Massachusetts has a comprehensive regulatory scheme for conservation easement termination. ${ }^{120}$ Governmental holders must provide public notice and hold a public hearing before any easement termination, and a nonprofit holder must obtain local government approval after a public notice and hearing in addition to obtaining EOEEA approval. ${ }^{121}$ The four factors considered for easement approval must also be considered before termination: (1) public interest; (2) any relevant government conservation program; (3) any public land use comprehensive or development plan; and (4) any known proposal by a governmental entity for use of the land. ${ }^{122}$ In addition, Massachusetts will not release easements purchased with state funds unless the landowner reimburses the holder at the current fair market value of the easement. $^{123}$

\section{Montana}

Montana restricts amendment and termination of conservation easements in two separate statutes: an enabling statute and a government parks law. ${ }^{124}$ All conservation easements fall under the restrictions in the parks law that restricts "conversion or diversion" of park land for non-park uses unless necessity, absence of any conflict with local planning, and substituting conservation land with adequate fair market value and conservation value. ${ }^{125}$

\section{Nebraska}

Nebraska's statute requires governmental approval of conservation easements on the front end and has comprehensive frameworks for

118. Id. at 17.

119. Id.

120. Id. at 23 .

121. Id.

122. Id.

123. Id. at 23-24.

124. Id. at 24 .

125. Id. 
amendment and termination. ${ }^{126}$ The Nebraska statute addresses four common methods for possible amendment and termination (mutual agreement, landowner court action, holder court action, and unilateral release by a holder) and it provides procedural and substantive guidance to the parties, government, and the courts. ${ }^{127}$ It is helpful to quote two relevant sections of Nebraska's statute in full:

Section 76-2,113-Easement; release or transfer. (1) A conservation or preservation easement may be released by the holder of the easement to the owner of the servient estate, except that such release shall be approved by the governing body which approved the easement, or if the holder is the state, a state agency, or political subdivision other than a city, village, or county, the release shall be approved by the state or such state agency or political subdivision. The release of an easement may be approved upon a finding by such body that the easement no longer substantially achieves the conservation or preservation purpose for which it was created.

Section 76-2,114-Easement; judicial modification or termination. Unless a conservation or preservation easement is otherwise modified or terminated according to the terms of the easement or the provisions of sections 76-2,111 to 76-2,118, the owner of the subject real property or the holder of the easement may petition the district court in which the greater part of the servient estate is located for modification or termination of the easement. The court may modify or terminate the easement pursuant to this section only if the petitioner establishes that it is no longer in the public interest to hold the easement or that the easement no longer substantially achieves the conservation or preservation purpose for which it was created. No comprehensive economic test shall be used to determine whether the public interest or the conservation or preservation purpose of the easement is still being served. No modification shall be permitted which is in excess of that reasonably necessary to remedy the deficiency of the easement. ${ }^{128}$

\section{Maine}

Maine overhauled its amendment and termination provisions in 2007, and like Nebraska, the provisions now address all of the most common amendment and termination methods. ${ }^{129}$ Maine has the most acres under easements and the largest conservation easement ever, over 750,000 acres. ${ }^{130}$ The many reforms included requirements for: (1) public registration; (2) easement monitoring; (3) using the attorney general as enforcement backup; (4) easement amendment and

126. Id. at 24-25.

127. Id. at 25 .

128. $I d$. at $24-25$.

129. Id. at 25 .

130. Pidot, supra note 4, at 6. 
termination; and (5) safeguarding easements from tax foreclosure of the landowner's interest or merger of the easement and fee. ${ }^{131}$

Maine requires registration of all types of conservation easements and all holders must annually register with the State Planning Office. ${ }^{132}$ The State Planning Office maintains a user-friendly online interface for registrations and annual updates, and they are required to report to the attorney general when easement holders fail to register. ${ }^{133}$ The attorney general has authority to enforce the registration requirements by order, but there are no sanctions or financial penalties for violations. ${ }^{134}$

Maine requires that all conservation easement holders monitor the easement, and they must report the last date the property was monitored in the registration statements. ${ }^{135}$ The law requires that each holder "shall monitor the condition of the real property . . . at least every three years and shall prepare and retain a written report in its permanent records."136 The Maine statute gives the attorney general specific backup enforcement powers, and limits the attorney general's broad authority over conservation easements as charitable trusts. ${ }^{137}$ Specifically, the attorney general is authorized to initiate enforcement of a conservation easement only when the party with the right to do so: (1) "[is] no longer in existence; (2) [is] bankrupt or insolvent; (3) cannot be contacted after reasonable diligence to do so; or (4) after 90 days' prior written notice ... [has] failed to take reasonable actions to bring about compliance with the conservation easement." 138

Maine's statute covers the process and substance of easement amendment and termination. ${ }^{139}$ The language does not specifically reference the charitable trust doctrine, but the law effectively does the same thing. ${ }^{140}$ First, approval is required for any termination or amendment that "materially detracts from the conservation values intended for protection." 141 A holder wishing to avoid possible enforcement action by the attorney general for amending or terminating an easement, later found to violate this standard, may seek informal advice from the attorney general's office concerning whether the amendment requires court approval under the materially detract standard. ${ }^{142}$ Second, the attorney general must be a party to any court action seek-

131. Id. at 7.

132. Id. at 9 .

133. Id.

134. Id. at 10 .

135. Id. at 12 .

136. Id. (quoting Me. Rev. Stat. Ann. tit. 33, § 477-A(3) (Supp. 2012)).

137. Id. at 14.

138. Me. Rev. Stat. Ann. tit. 33, § 478(1) (Supp. 2012).

139. Pidot, supra note 4 , at 16-17.

140. Id. at 17.

141. Levin, supra note 4 , at 25.

142. Pidot, supra note 4 , at 17. 
ing approval for amendment or termination. ${ }^{143}$ Third, the court must base its approval on consideration of the conservation purposes expressed in the easement, as well as public interest, and other relevant factors. ${ }^{144}$ Finally, if the value of the landowner's fee interest increases as a result of the amendment or termination, that increase must be paid to the holder or to such nonprofit or government agency as the court designates, to be used for the protection of lands consistent, as nearly as possible, with the easement's stated conservation purposes. ${ }^{145}$ Maine's statute might be interpreted to provide more flexibility for courts concerning amendment or termination than the cy pres standard under the charitable trust doctrine or the extinguishment standard under the Regulations applicable to tax-deductible easements. ${ }^{146}$ Maine's Act has been seen as a model reform act for other states to follow, and acts as guidance to its courts, perpetual easement donors, and holders beyond that offered by the UCEA, and is consistent with the Restatement and Regulations. ${ }^{147}$

\section{B. Standing of States' Attorneys General}

The states in which the attorneys general have standing to enforce conservation easement amendments and terminations include Arizona, Connecticut, Illinois, Maine, Mississippi, Tennessee, and Virginia. States that have expressly prohibited their attorneys general from standing to enforce amendments and terminations are Alabama, Montana, New Mexico, South Dakota, and Wyoming. ${ }^{148}$

Tennessee even expanded enforcement power beyond the attorney general. For example, in Tennessee Environmental Council v. Bright Par 3 Assocs., a resident sought to enforce a conservation easement on the South Chickamauga Creek granted to the City of Chattanooga, Tennessee. ${ }^{149}$ The conservation easement prevented the discharge of pollutants, and the allegation stated the construction of a Wal-Mart Supercenter and a strip mall on the encumbered land would result in illegal discharge of pollutants and cause irreparable harm. ${ }^{150}$ The relevant Tennessee statute stated: "[c]onservation easements may be enforced by injunction or proceedings in equity by the holders and/or beneficiaries of the easement, or their bona fide representatives, heirs, or assigns." 151 The Court of Appeals interpreted beneficiaries to mean that a conservation easement is "held for the benefit of the people of

143. Id.

144. Id.; Me. Rev. Stat. Ann. tit. 33, § 477-A(2)(B) (Supp. 2012).

145. Pidot, supra note 4, at 17.

146. Id. at 19.

147. Jay, supra note 1 , at 77-78.

148. Levin, supra note 4, at 31-32.

149. Tenn. Envtl. Council, Inc. v. Bright Par 3 Assocs. L.P., No. E2003-01982-COAR3-CV, 2004 WL 419720, at *1 (Tenn. Ct. App. Oct. 4, 2004).

150. Id. at $* 2$.

151. Tenn. Code Ann. § 66-9-307(b) (2005). 
Tennessee," and that "any resident of Tennessee has standing to enforce it." 152 The Tennessee legislature did not adopt the specific language of the UCEA that restricted the enforcement of a conservation easement to "a governmental body, charitable corporation, or association with the specific right granted in the document."153

By contrast, after thoroughly examining the Restatements of Law for Property and Trusts, two judges in separate, more recent, judicial decisions rejected applying charitable trust doctrines to perpetual conservation easements. In the consolidated case of Carpenter v. CIR, the IRS filed a motion for summary judgment, because the terms of the agreement allowing extinguishment of the conservation easements based on mutual agreement did not protect the easement in perpetuity-a requirement for the tax deduction. ${ }^{154}$ The respondents claimed that the conservation easement donations created a charitable trust and would require a cy pres court hearing before the conservation easement could be extinguished. ${ }^{155}$ The tax court, following Colorado law, held the conservation easements did not create a charitable trust. Absent a ruling by the Colorado Supreme Court:

We do not find any clear, explicit, definite, unequivocal, and unambiguous language in the conservation easement deeds to create a trust. We also do not find any intention to create a trust. As a result, we do not find that petitioners created charitable trusts under Colorado law with their conservation easement deeds. ${ }^{156}$

In Long Green Valley Ass'n v. Bellevale Farms, the Court of Special Appeals of Maryland rejected that Long Green Valley Association ("Association") had standing as a third party under the charitable trust doctrine to stop construction and operation of a creamery on a conservation easement owned by Maryland Agricultural Land Preservation Foundation ("MALPF"). ${ }^{157}$ After a detailed discussion of the charitable trust doctrine and the debate over whether those principles should apply to conservation easement amendment or termination, the court held that the easement was not perpetual and the element of intent to create a trust was not present. ${ }^{158}$ The Association appealed and the Court of Appeals of Maryland answered a question of first impression and held that an "agricultural preservation easement ... purchased by a Maryland state agency from a private landowner" did not create a charitable trust that would afford "non-party interested persons standing to seek enforcement." ${ }^{159}$

152. Tenn. Envtl. Council, $2004 \mathrm{WL} 419720$, at $* 3$.

153. Id.

154. Carpenter v. Comm'r, T.C.M. (CCH) 1001, at *3 (2012).

155. Id.

156. Id. at *6.

157. Long Green Valley Ass'n v. Bellevale Farms, Inc., 46 A.3d 473, 487-502 (Md. Ct. Spec. App. 2011).

158. Id.

159. Long Green Valley Ass'n v. Bellvale Farms, Inc., 68 A.3d 843, 845 (Md. 2013). 
One case dealt directly with conservation easement amendment, Bjork v. Draper, and involved an issue of whether a conservation easement on the Drapers' property, managed by the Lake Forest Open Lands Association ("LFOLA"), could be amended. ${ }^{160}$ The easement protected the historic home and its openness to public view. ${ }^{161}$ The Drapers wished to amend the easement and the LFOLA agreed. The Bjorks lived within 500 feet of the encumbered property, they objected to the amendments, and they had standing to sue under Illinois's easement statute. The lower court ruled the amendments violated the easement because the plan would contravene the easement's purpose by obstructing the public's view of the property. ${ }^{162} \mathrm{On}$ appeal, the court agreed that the amendment was permitted per se, not because of the state's enabling act, but because the easement contained an amendment provision. ${ }^{163}$ The court reasoned that the amendment provision was allowed because the term "perpetual" refers to the conservation purpose, and not to the easement itself. ${ }^{164}$ Specifically, the court said:

[A]lthough the easement sets forth that the conservation values of the property are to be protected in perpetuity, it does not logically follow that the language of the easement could never be amended to allow that to occur. Indeed, it is conceivable that the easement could be amended to add land to the easement. Such an amendment would most likely enhance the conservation values of the property. ${ }^{165}$

This reasoning is consistent with the Regulations because it emphasizes the continuation of the easement's purposes and expressly allows amendment to further those purposes, but it allows amendment without judicial oversight. ${ }^{166}$

\section{Adaptive Land Management Concerns and Analysis}

Conservation easements are a hybrid-law creation and their enforcement, amendment, and possible termination requires a hybridlaw solution as well. States are unlikely to agree whether or how the charitable trust doctrine or real property law should be applied to conservation easement amendments. There are too many variables to consider when applying the charitable trust doctrine or real property law: state and federal budgets, donor intent, the ability of land trusts or governments to maintain the easements, state attorney general involvement, changing public policy, the public's interest in perpetuat-

160. Jay, supra note 1, at 34-35; see Bjork v. Draper, 886 N.E.2d 563 (Ill. App. Ct. 2008).

161. Id.

162. Jay, supra note 1, at 34-35; Bjork, 886 N.E.2d at 563.

163. Bjork, 886 N.E.2d at 572.

164. Id.

165. Id.

166. Jay, supra note 1 , at 27. 
ing the easement, and climate change realities. One could attempt to add provisions to the original conservation easement agreement to account for every possible situation, but one would most likely fail to consider that perpetuity lasts a long time.

Another factor that the federal government and states need to consider is the effectiveness of perpetual conservation easements in light of climate change. Some have suggested that conservation easements may actually hamper environmental protection and "fail to accommodate the reality of environmental problems." 167 Merely relying on private land conservation may be an inadequate means of addressing increasing environmental problems. ${ }^{168}$ Conservation easements could actually promote complacency in legislatures; legislatures could conflate the increasing acreage under conservation easements as meeting environmental conservation goals. ${ }^{169}$ Land preservation is important in mitigating and adapting to climate change and when private parties and organizations conserve land, the government benefits because private actors are carrying out actions the government might otherwise take on. ${ }^{170}$ There are four main problems with conservation easements in addressing climate change. First, conservation easements are a creature of statute because common law servitudes created impediments to enforcement. ${ }^{171}$ Second, the widespread use of conservation easements as a conservation strategy raises questions of accountability, enforcement, and democracy because private organizations are taking on the regulatory function of environmental protection without the same oversight. ${ }^{172}$ Third, conservation easements are not an ecologically sound method of conservation. Lastly, conservation easements are not accomplishing what we think because they fail to protect long-term conservation efforts when they are unenforced or are unenforceable. ${ }^{173}$

Gains from conservation easements may be overstated: "[for] instance, land trusts may take credit for all acres acquired through fee or conservation easement as the amount of land saved, but only a portion of those acres were likely to have been developed or converted to other land uses without that acquisition."174 Similarly, conservation easements located on land with a low-threat of development may only slightly mitigate habitat loss, because development could shift to unencumbered parcels in the habitat. ${ }^{175}$ When one considers storms,

167. Owley, supra note 7, at 122.

168. Id. at 123.

169. Id.

170. Id. at 142 .

171. Id. at $142-44$.

172. Id.

173. $I d$.

174. Adena R. Rissman, Evaluating Conservation Effectiveness and Adaptation in Dynamic Landscapes, 74 LaW \& Contemp, Probs. 145, 150 (2011).

175. Id. at 165 . 
human behavior, grazing, fires, or invasive species one can see that ecosystems are dynamic and non-linear. ${ }^{176}$ As it stands today, a conservation easement's ability to conserve property in perpetuity is appealing but unrealistic.

Adaptive land management principles could aid conservation easement effectiveness. Adaptive land management is a system involving alternating conservation management strategy because of monitoring feedback-essentially treating differing management approaches as experiments. ${ }^{177}$ A conservation easement incorporating an adaptive approach would have clear conservation purposes; established links between those purposes and compliance terms; an enforcement or monitoring mechanism; and a framework for changing strategies based on feedback. ${ }^{178}$ Where incorporating active management terms in a conservation easement might be too prescriptive, one could add a dynamic easement term to the agreement-comply with state's best management practices for water quality. ${ }^{179}$

Some suggest it is possible that a landowner and conservation easement holder could agree to terminate a conservation easement at the end of the term for a term-terminable easement. ${ }^{180}$ Others have also recently called for term-terminable easements. ${ }^{181}$ But where shortterm easements are protecting agricultural land and the increase of corn prices are driving up the value of farmland, these short-term easements are a threat to wetland and grasslands because they are terminable without renewal or approval. ${ }^{182}$ Any future change in the perpetual nature of conservation easements would disqualify them from federal tax subsidies unless Congress changes the Tax Code. With the current political climate and looming tax reform, it is possible that Congress could cut tax deductions if they view them as ineffective.

Conservation easements are a hybrid-law creation and their enforcement, amendment, and termination should be a hybrid-law solution as well. The answer might not be as black and white as charitable trust doctrine versus real property principles. For conservation easements to evolve to meet the challenges of climate change, state laws require frameworks to meet those challenges and the debate over the applicability of the charitable trust doctrine might not matter. No matter what, state legislatures and Congress will have to decide if perpetual conservation easements are meeting our conservation needs or not in light of climate change. The federal government already gives

176. Id. at 151.

177. Id. at $152-153$.

178. Id.

179. Id. at 155 .

180. Id. at 166; see McLaughlin, supra note 62, at 675.

181. Id.

182. Rissman, supra note 174 , at 167. 
sizeable tax deductions because the public values open spaces, historical sites, and natural resources-and protecting them in perpetuity is at the heart of the Tax Code. Are taxpayers getting their money's worth or are millions of acres under easement actually serving a "negligible" benefit?

Unless Congress reforms the Tax Code, the solution lies in the state legislatures. Legislatures should pass laws setting up frameworks that take into account standing, enforcement, amendment, termination, climate change, dynamic terms, and clearer purpose statements. Whether states follow charitable trust doctrines or real property principles is less important than having a framework that is predictable and enforceable. If states follow Maine and Massachusetts, the framework might look more like state environmental protection agencies that review, approve, monitor, and enforce the conservation easements. This additional oversight would solve one problem with the current private "regulation-like" system of conservation easements.

State environmental protection agencies, instead of the office of the attorney general, could handle enforcement and amendments with the attorney general as backup enforcement. The state agencies could: (1) evaluate the ecological, historical, and scenic value of the proposed perpetual conservation easement on the front end (as pre-requisite for state tax-deduction); (2) serve as checks and balances for amendments and terminations proposed by the parties of conservation easements; (3) periodically review the effectiveness of ecologically important easements; and (4) tie easement terms to the appropriate dynamic measurements depending on the type of land being conserved. The state environmental agencies already have specialized knowledge and skills to tackle environmental protection issues and could relieve overwhelmed attorneys general offices. With current comprehensive enforcement and monitoring systems in a few states, the purpose of the conservation easement is periodically assessed, which would make adding dynamic easement terms or re-assessing conservation effectiveness fit into those states' frameworks pretty easily.

\section{Conclusion}

The debate over whether to apply the charitable trust doctrine and cy pres proceedings to conservation easement amendment and termination is far from settled. State legislatures are either silent or disagree on how to approach the amendment situation. A uniform approach to conservation easement amendment and termination across all fifty states, or adopted by the UCEA is unlikely. State legislatures may choose Maine as the model for a comprehensive approach to amending and enforcing conservation easements, which might further charitable trust doctrines or, when codified, meld them with components from property law for a hybrid solution. Right now, uniformity is unlikely, but state legislatures should pass legislation 
creating comprehensive frameworks for monitoring, amending, terminating, and enforcing conservation easements to avoid ambiguity and protect their investment. 